\title{
一一第四回 全国地理学卒業論文発表大会—
}

本学会主催の全国地理学卒論発表大会も回を重ねること四回に及び，今年は去る 3 月 18日午前 9 時より東京学芸大学竹早校舎に肪いて行われた。

この大会は回を重初る毎に数多くの発表者を得，今年は関東近県招よびはるか鳥取大 ・立命館大・大阪市立大など 27 名にも及び会場を二つに分けて行つた注でで, わが国 唯一の特色める研究大会の一つとして, 主慛者にとつてる感慨を新たにさ中る活どであ つた。発表の内容も着実に現象を捉えた分析をし，地理学研究の成果を向上せしめるも

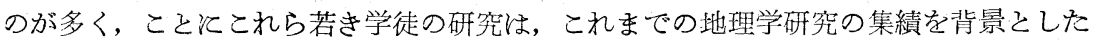
あのであつて, この点地理学の古今括よび将来へつ歩みを再び認識せしめるに，この上 ないよい機会であるものと思う。例年発表者には，その記念として将来地理学及び地理 教育の発展に一層の新風を加えられることを念願して, I. Bowman の The New World 4th editionなど外国のすぐれた研究書を贈呈して来たのである。これら諳君の今後の 努力を期待するとともに, 来年の発表大会にはより多くの参加者を得たく, 各大学地理 学教室の方をにその推鹰方を依類する次第である。

\section{卒論発表大会発表要旨}

\section{1. 雄物川上流に於ける経済地理的研究}

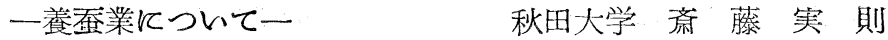

秋田県の県南を流れている雄物川の上流部には幾つかの支流河谷が形成されているが， この地域では米作が農民生活の基盤てなつているとはいえ，農作物の栽培景観が下流部 の秋田平野，中流部の横手盆地の米作単作地帯と忹，やや趣を異にして招り，松井勇氏 の軖業経営の形飞依る分類からすると，秋田県は大部分耕種養虫地域となつているが本 地域は耕種養㔻地域として示されている。一般に農作物の栽培経営形態は農業現象の中 で土地と作物を対象とする極限とされたもので，労働力・資本位置的の制約のもとに特 ける形営形態の最も標式的且つ具体的はもので自然に対する適応の形をよく示している ものと思动る。

かかる観点から上流部の農業栽培形を特色づけるのの一つとして桑園を，そしてと

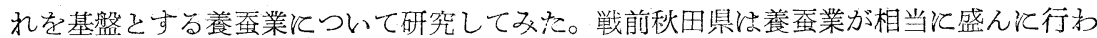
れ大正14年にはまゆの産額41万貫で全国第五位を占めていたが以後减少を，続け現在で は年産約 6 万貫で隣県山形県の 1 割飞も及はないのであるが，この雄物川上流部は秋田 県養虫業の核心地域となつて扣り，常にとの指導的立場を維持してきたのである。現在 は全県の 4 割の桑園と 7 割以上の秀ゆの産額を示している本地域の養蚕菜を次の諸点か ら洘察し分析してみた。

自然的条件-D-桑園の立地內子の分析

位置的条件一仙台との交通の歴史的究明 
地方地主一一親方と養寔業の発達

労働構造面からの分析

むずび 本地域の養亘業は他の数多くの副業及び特産物と共と副業で水田農業が基盤と なつているとと, 本地域の養虫業の推移を地域的に見ると河谷上流部の山村部が核心地 域となつて括り冷害多被害地帯と一致する。養㫤業もとれそ同じく本地域の過剩労働力 の商品他されたものでそこで営亲れる農家は貧しい。

\section{2. 都市近郊果樹栽培地域の地理学的研究}

一特に多摩川の梨・桃栽培の場合一 東京学芸大学 大烟 実

1. 序論 都市近郊果樹栽培が遠郊果樹栽培地域と対抗して存続する場合々は, 特

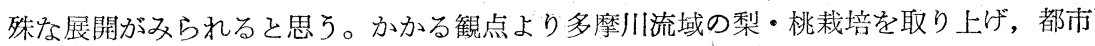
近郊果樹栽培地域として, 本地域の地域性をつかもらとした。調查範团は, 川㥓市中原

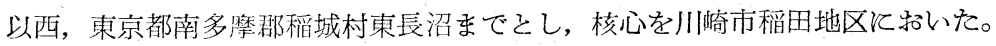

2. 本論本地域の梨・桃栽培の分布をみると, 桃は, 下流域に多く分布し, 梨は 桃栽培地域上り上流，即ち登戸以西汇多く分布する。

梨栽培のうち，交通的都市ともつとも近距離にある登戸周辺は二十世紀梨が多く分 布し, 上流にいくと長十郎梨が多く分布する。この上う亿分布上の三形態は, 土壤, 気 温, 等の自然条件では決定しがたく, 土地所有上の地主と小作との関係が桃と梨の栽培 上のちがいを，又「もぎとり」とよる高収入が二十世紀栽培地域龙決定している。

いずれそしても, 桃栽培地域, 二十世紀桟栽地域は, 自然条件及び社会条件にもめぐ まれないにも尔かわらず，都市消費地の動向をつかむととによりて経営をなりたたせて 招り, 乙か子高収入を得ている点で恃色がある。又東京市場で, 遠郊地のるの亿対し 本地域の桃・二十世紀梨の単価が，他府県を压していることは，量で拓されているのを 扣ぎない，又本地域の各栽培地の立地々あわせて考元ると興味樑いことである。

3. 結論 本地域の果樹経営は, 最先端及び交通的利点をしめる地域は, 投機的色 彩の濛い傾向をみ, 最先端では桃が, 交通的利点地域は, 二十甘紀栽培が物こなかれる 特色をみるのである。

\section{3. 山村の経済地理学的研究}

一特化六合村の場合一

群馬大学 松 井 雄 司

亲合村は群馬県北西部の山村であり, その経済的基盤は古くより農業と林業を主とし つつも, 自然的制約の結果は農耕地の䔈少及び栽培作物々拁いてる, 自給食糧を生産す る正亦る。しか子完全なる食糧自給は不可能であつて, 必然的飞兼業が行れれる。か くの如き経済形態の内部構造分析によつて, 本地域の特性を明らかてする。特て土地利 用と農業経営構造との関連について究明するととを目的とする。

村內の全農家 456 戸について昭和 28 年度の村民税申告書より収入の形態を分析し, ま た県夏期調査結果によつて，農業関係資料を得た。一方地形的制約下にある土地利用状 態を実地調査及び地割図により考察した。本地域の農家は耕地所有面皘子極めて低く, 更に高冷地域として農業発详も充分で斿ない上上の結果を以て有機的定量的な考察を 
行つた。

経済活動の基盤たる収入の形態を四分類してみると，農業収入は全収入中の $33 \%$ ，林 業収入は $22 \%$ 強であり（全村平均）他は養亰，雑収入となつて括り，定量的にも山村的 性格を示す。一人当り経営規模と農業収入との間に恃, 後者が33\%以上の部落で相関関

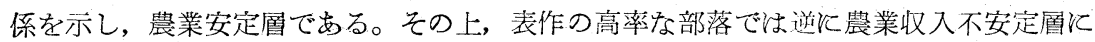

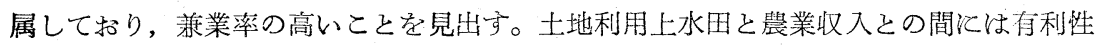
は認められず, このととは稲作経営の不振を物語ると共水稻の自給的色彩の強いこと を示している。をた農業経営規模の大なる入山括いて全収入が一般に低位を示してい ることは，地形的制約と共に気温の低い高冷地性の結果である。農業収入に叔ける特殊 な例として最近端菜栽培が著しくなり，麦作と代つて有利な土地利用を行つている。ふ くの如く本村恃農業経営に叔いて次第自給的農業から換金作物化へと交通の発達に伴 つて転換が見られるのである。

\section{4. 尾張平野南部の農業労働の需給地域}

愛知学芸大学 加藤 秋

筆者は尾張平野南部の農業学㗢 (田植労働) の需給地域を展望し, その移動方向と形 成要因を究明せんとした。

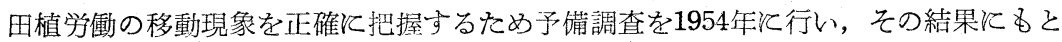
ずいて1955年に25ケ市町村の農家1993戸を調查した。又同年 8〜10月と最南部地域を部 落別々聴き取り調查を行い，両者を比較検討し根本的な誤りがなかつたので其れを集計 ・分析した。な敃資料を集める時その都度関係各市町村の農家を歴訪して検討し誤差な きととを確かめた。

成果……(1)現今に於ける田植学力の招子な移動方向は南部（新田地域）から北部（古 田地域)への移動と南部相互間の移動である。その逆流である北部から南部への移動は 少ない。とれは結局用水分配の相違による農繁期の時期的なずれて農地改革前々㑧いて 南部に小作農多く，漸次北進するにつれて自作農が多くなるというように相対的に貧農 地域から富農地域への移動である。（経済流）

(2) 戦後農作物の好景気と小作農から自作農化するに及んで農家経済力の増加化伴な い田植労務者を雇う農家が増大し，とくに南部の新田地域において其の現象が顕著であ るため北部 (古田地域) から雇うこえが現在沉括いては出来ないと云う理由から南部新 田地域の同規模農家の相互交流現象となつた。

(3) 雇傭労力の需給地は婚姻関係に括计る「手間」の交換地域とよく一致している。 即ら当地域は古来「手伝ひ」又「手間」の学力交換が現今に括いて雇傭形態に変化した もので本来の「手間」の労力交換の性質から完全に脱皮していない。

な扮，かかる南部の水田大経営地域が経済力を一層向上するならば，かかる相互移動 はなくなり，反対に経済の低い周辺の山地ふら労力を人れるようになるであるろ。 


\section{5. 山梨ホツプの地域的研究}

一北多摩郡下における栽培一梨大学 村上一 郎

序 ビール 1 石の醸造に約 $0.5 \mathrm{~kg}$ を必要とするホツプはアサヒ, ニッポン, キリン のビール三社により北海道・山形・福島・長野・山梨の一道四県につみ契約栽培が行わ れている。アサヒ・ニツポン社（共同管理）は全国 792 トンの $65.9 \%$, キリン社は全国 の34.1\%，山梨はキリン社の $25.3 \%$, 北多摩は県下の $93 \%$ 导生産している。（昭和 29 年 平年作（本地域は概高 $325 \mathrm{~m} \sim 1080 \mathrm{~m}$ （役場所在地）飞位し地形・気候・土壤等自然条 件の差異により各地の風土，ての表現体である植生，ひいては農業経営の 7ype にいた るまで様々な pattern の多様性を示している。本研究は本地域の招もな副業——北部 のホップ, 南部の養虫穵とりあげ耕地率・戸数率の郡平均と各町村のとれとの比較によ り，その分布をとらえ，この分布と農業経営の様式（農事暦）とを関連づけ昭和15年郡 下全町村に開栽されたホツプが戦争を契機として炤和30年現在, 北部（八ケ岳南麓丘陵 地帯）に集中した理由を追究し，外国ホツプとの比較，養峑業との関係をもとりあげ副 業としてのホツブ栽培をより明確に定義づけ，わが国のホップ栽培業に何らかの示唆を 与えようとしたものである。

結語 (1)ホツプ栽培業の将来性をみるに, 商業資本と直結し, ビール工業の進准に伴 い益々有望である。(2)本地域では八ケ岳南部の丘陵地带を中心とする鉒無川上流から 茅ケ岳北西麓部の標高約 500〜 1000m の地域が適地と考えられる。(3)茅ケ岳南西麓部 を含む約 $500 \mathrm{~m}$ 以下の地域は養㔻の適地と考兵られる。(4)以上, 適地適作主義の立分 な認識徹底に基く風土産業の興隆をもたらすととが今後の農村乃至農業経営にとつて必 要不可欠であること再確認するものである。

\section{6. 鳥取砂丘の自然地誌的研究㐆取大学 福 本 公 規}

この研究は粒度分布を地理学的に分析することによって, 現在の景観を露呈するに至 つた過程一一特にその移動の機構を究明せんとしたものである。砂丘の砂は主として砂

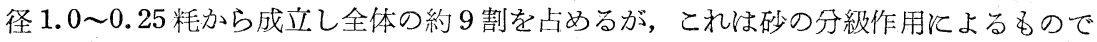
ある。平均粒径の分布図を見るとその等值線は大体地形の等高線浴つて変化して招り, 分級度を四分偏差で表現すると同様な変化を示し，いづれもS E方向に伸びている。こ れは砂丘の起伏が砂の移動に大きな因子となつているとと学すすのである。砂丘の砂 を汀線部の砂, 砂浜地带の砂, 砂丘部の砂分けてみると, 汀線部の砂々よくふるいわ けされて粒径 1.0 0.5mm の砂粒が大部分を占め, 砂浜部の砂は 0.5 0.25 $\mathrm{mm}$ の砂粒 が相当混り，ふるいわけの度合いは悪い。砂丘部の砂は 0.5〜0.25 $\mathrm{mm}$ の砂粒が大部分 を占めるようになりよくらるいわけされている。即ち平均粒径, 四分偏差も砂浜地带で 急激に変化し, 砂丘地帯に入ると著しく安定してくるのであつて, そつ差異が明膫に表 わされる。次に砂の移動量は実測によつて風速の 5 次式で表わされ, $10 \mathrm{~m}$ 以上の風速が

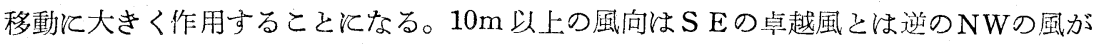
卓越し, $\mathrm{ENE} \sim \mathrm{WSW}$ に走る海岸線に対してN側と S 側の風の経続時間比は 4:1であ つて，平均粒径の等值線が全体としてS Eに伸びていることを信証している。しかもそ 
の時期は冬季から春先にかけてであつて，夏季には殆んぞ移動しない。頂上は風下斜面， 底部に比して風速, 乾燥度が大きいため, 特に降雨後は砂丘を S E 側に移動させながら 起伏を平均化させ, 全体的に忤間約 $1 \mathrm{~cm}$ の堆砂が推定される。

従つて現在の景観は以上のような条件によつて生成されたと思われるが，複雑な起伏 の生成については今後研究してみなければわからない。

\section{7. 大磯地塊における河岸段丘横浜国立大学 井 出 保}

大磯地塊は丹沢山地の南部に秦野盆地を挾んで存在する地塊山地で, 秦野盆地陷没に よつて生じた三本の截頭河流を有している。現在迄のこの地域に関する研究は主として 地質学的研究にのみ片寄り地形学的考察には欠けていたように思われたので, 筆者は主 として地形学的考察, そくに截頭前の河岸段丘と截頭後の河岸段丘との比較により本地 塊に挌ける最近の地盤運動を導き出さんと試みた。段丘面の復旧に際してはトランシツ 卜測量を行つた。

その結果段丘面を第六段にまで分類することが出来，第四段までが截頭以前のものと わかつた。この第四段丘は岩石段丘で段丘面上に $25 \mathrm{~m}$ 程の厚さの礫層を有しているとこ ろも女るが, 段丘面上には厚さ $1 \mathrm{~m}$ 程のローム層が存在する。第三段丘面上には数 $\mathrm{m}$ 以 上のローム首が存在する事から考えて渋沢断層はローム層堆積期末期に生じたものと考 えられる。

第一段丘は殆どその形跡を留めないがその高度位は判別出来る。それによると第五段 丘面との高度差は約 100 mである。これは洪積期末期の隆起運動が少くとも $100 \mathrm{~m}$ 以上 であつた事を物語るすのである。第五段丘は主として下流が海成, 上流が陸成の沖積層 から成つているが，その海成的性質は地塊内部にまでも入り込んでいてその高度は $55 \mathrm{~m}$ でむる。従つて沖積期初期の沈降運動は少くとも55m以上は安つた筈であり，その後現 在迄 $55 \mathrm{~m}$ 程隆起していることになる。各段丘の勾配を見ると, 各段丘の勾配が古いもの ほど緩かであるととから，各運動が北方傾斜運動であつたと考光られる。それは地層が 北方に傾斜していること。関東大地震の際にも三浦, 房総と共に北方傾斜運動を示して いるこそに依つても当然うなづけることである。又三河川に括ける截頭前の段丘の高度 は東に行く程低くなる。押切川之不動川ではその差は第三段丘で約 $10 \mathrm{~m}$, 第一段丘で約 $20 \mathrm{~m}$ である。それはそれ迄の各運動が北方傾斜運動であると同時化東方傾斜運動でも女， つたことを物語るものである。

\section{8. 葛生石洃礦業の地理学的考察}

一立地条件について一

宇都宮大学山口仁

足尾山地南東部に, 良質な石灭岩・苦灰岩が互層となつて, 大規模な馬蹄形状々分布 している。此の中の葛生地域には, これらを原料とする石死碏業が, 近年, 急速な発展 をとげている。これの主要な立地条件について考察した。

47 の採掘場が分布し，2力所の七メント用の石灰岩を採掘している。その方法は, 露 天掘式断崖掘で, 切羽飞接近して生石灰・消石灰・プラスター・タンカル・苦土灭・ク リンカー製造工場が立地している。その生産は, 年々増加の傾向にあつて, 炤和 29 年石 
灰 233,439トン, この内, $79 \%$ が工業用灰で, 累年, 圧倒的に多い。自然的素因と歴史 的・社会的素因が相互に関係し有利な立地条件となつている。然料として, 石灰・コー クスを混洧使用しているが, その産地が地理的に遠隔であるため輸送関係に於て有利で ない。切羽から製造工場への原石輸送・工場から消費地への製品輸送の円滑化が, 重要 な条件をなしている。

農村の安価な学働力が使用され，これを通じて，農村と礦業が密接に結びついている。 クリンカー製造工場は地域外資本に支配され, 石灰製造工場は小規模な設備で簡単な生 産工程のため地域内資本によつて経営されている。農業用灰の商圈は, 浜松一糸魚川を 結ぶ線より以東，工業用灰の商圏は，京浜工業地帯を中核として全国的である。

これらを綜合すれば, 原料が，比較的安価で非常に重量のために製造工場は，原料生 産地に吸引される傾向が強い。このため, 大消費地と近接し, それを結ぶ交通の利便は 欠くことの出来ない重要な指導的立地因子で, 安価な労㗢力, その他幾多の因子と相互 に関連し合い，葛生石灰礦業が成立している。

\section{9. 筑豊地域鉱害農村の地理学的考察（発表要旨未着）}

$$
\text { 明治大学 田中留 雄 }
$$

\section{0. 中国地方山村の人文地理学的考察 (発表要旨未着)}

一未ると下高野山村における株小作と「たうら」を中心として一 駒沢大学 栗 部 純 光

\section{1. 地域現象の結合とその変貌過程}

一高萩㞸鉱地域の場合一

荻城大学宮田 祝 男

常磐炭田南部の各炭鉱は概ね，明治30年前後て企業化されている。これらの各炭鉱は 農村集落等の内部，又は隣接地に開発され，鉱業人口を集中せしめ炭鉱集落を構成して 来ている。これら農村集落と炭鉱集落の異質的社会機構間々於ける結合，離反関係等を 考察し，両者の機能が如何なる相互作用を有しつつ地域社会の形成を進展せしめたが 研究の課題を扔く。

対象地域は茨城県内屈指の鉱業所を有する高萩市であるが, 此の課題考察の指標とし て人口流動, 商業機能, 農村経済, 関連工業の発達等を求めた。資料は各官厅会社統計, 実地調查の他に当地への移住理由, 前職歴などを調査用紙によつて調査, 整理した。

炭鉱集落と隣接の他集落との直接的相関の主なるものは，1）炭鉱集落の発生，拡大 が強制的，且急激である為に，労働力の交流を媒介とする場合情弱。2）野菜等の消 費による農村経済との連関は，距離と相関にあるが，鉱業地に対する隣接地の積極的関 与の意欲はみられない。3）失業，鉱害等の利害関係は内的結合としての通婚関係なぞ を生み難い。4）然し関連工業の発達，消費需要量の拡大に伴う商業の発達等がみられ それらを通じての地元隣接地との結合が強い。

即ち農村を主体とする在来地域の知会機構と機能㥀接炭鉱の生産的活動の地域集団 
そ結合することは徴弱であるが, 複合的な関連工業, 商業機能, 野菜物の消費などを通 じて強く結合している。然るに炭鉱業は盛衰が甚しいので，これに結びつく小規模な関 連工業と商業活動も変貌は受け易く, 地域形成に当り諸現象を変改しつ〉, 且地域己の 結合を漸次強めて来ているのである。

以上 (1956. 3)

\section{2. 伊豆東部海区における地先漁業について}

東京学芸大学 加藤 泰 男

I 序 伊豆半島の東岸で行なわれている漁業を, 主として沿岸漁業業の面から考 察し，それが臨海市町村にどのような影響を与えているかを解明しようとした。

II 水産業の概況 本海区は沿岸漁業 $78 \%$, 沖合漁業 $13 \%$, 遠洋漁業 $9 \%$ で沿岸漁 業の占めるウエイトが非常に高い。これは色々な条件が重なつて生じたものであるが, 一つには沿岸漁場の優秀性があげられる。そつため漁業権は複雑でありまた貴重である。 次に漁港, 漁船の規模をみると, 漁港は第一種の小規模な漁港が多く, 漁船も伊東, 下 田両区のように 50t 以上の大型漁船を有する地もあるが，大部分は小型漁船で特に南部 の村々は無動力船が多い。

III 漁家の兼業関係沿岸総漁家数4427 戸のらち約半数の 2221 月の漁家他他産菜を 兼業し農業が大部分である。そして專業漁家の多い地区は釣漁業，農業を兼業する漁家 の多い地区は採貝藻漁業, 両者の中間で注定置漁業がそれぞれ顕著々行なるれている。

IV 臨海村の漁業依存度臨海14方町村を職業別構成よりみると, 水産業は平均し て28\%で低いが，沿岸部落のみてついてみると漁業依存度は高く，網代，稲取などほ純 漁村と云える。な扮水産業以外の産業をみうと，下田を除く白浜以南の地は農業が多く， 北部は熱海，伊東のように観光産業がそれぞれ多い。

Vさむび本海区は沿岸漁業が盛ん。゙北部は定置漁業, 南部は採貝藻漁業が卓越 し, 漁港, 漁船などは小規模なものが多い。沿岸の漁家のうち約半数は他産業を兼業し 農業との結び付きが深い。臨海部落を有する町村ほど漁業依存度は高いが, 漁業型態や 他産業との関係も考察する必要がある。合本論交作成々あたり色々御指導下さつた小栗 助教授感謝の意を表する次第である。

\section{3. 遠州織物工業の発生と継続}

静岡大学 田畑啓之

遠州織物工業は, 遠州平野, 特飞浜松市地域, 西南部地域, 北部地域の三地域に衫い て集中的に行われている伝統的工業である。北部地域に特いては小巾織物が，西南部地 域に括いてほ広巾織物が多く，浜松市地域に括いては両者の混合地域となつている。

歴史的には北部地域が最も古く, 浜松市地域がこはに次いでいる。遠州織物の初期は 北部地域の笠井市を中心として近隣の農村に次第に発展していつた。しかし東海道本線 の開通と共に市場は浜松市に移つた。これに伴つて織物子浜松市に移動した。第一次世 界大戦以降遠州地方は従前の小币織物に加えて広巾織物が普及して来たが，同時に市場 を国内から海外に向け，輸出織物として発展するに至つた。

三地域の内浜松市地域が中心的な位置を占め, 織布工場, 管捲, 撚系工場, 染色工場, 整理仕上工場など準備工程，製織工程，仕上工程が，分業と関係をもつて有機的々結 
合し，地域化産業の形態を取つている。織布工場及び関連工業は小規模工場が多く，従 つて, 家内工業的な色彩が濃厚であり, 遠州織物工業は家族労働力の上飞成立つている といつてよい。労働力の大部分は, 県内で賄われているが, 不足分は東北地方, 九州地 方の日本列島の両端から求められているといつた変つた型を取つている。

現在遠州織物工業は大部分が貢織の形態を取つて抎り，小币織物工業に括いては地元 問屋の，広巾織物工業に括いては大紡績会社，商社つ儧織を行つている。従つて遠州織 物自体は加工貫を得ていると過ぎない。

\section{4. 足利繊維工業の地理学的研究 宇都宮大学 白 沢 久 弘}

機業地として，社会的評価を与兄られていた足利も，第二次大戦を契機として，その 地位を失つたかてみえるが, 内部的には，これを機会に化学・機械などの他の工業部門 が芽生え，紡織部門に括いては，織物業の他に，新たに経メリヤス業が起り，それて伴 つて縫製業も加わつた。質的には，繊維工業の多くの分野を受つととそなり，労働人口 の，括よそ50\%は，この部門を対象としている。何故にこの地域に括いて，織物業が維 持されているかが，研究課題である。

この織物業は当初の原料供給地であつた東部の綿作地域と, 西部の養蚕地域に, はさ まれた畑作变換線的及び，交通的な占有性をもつて独自の製品を生み出したのであり， 又, 生産工程は多岐に分化したが，いわゆる仲介式織元によつて，分業的協業が行われ 古い技術が維持されている。近郊農村の性格とも相俟つて, 豊かな労㗢力を包容し，こ れが繊維工業の一般性と結合している。女子労働力が多く使われ，その質的な面と，経 営の零細性のためて家族的な雇傭関係が存在し, 又, 労㗢力の制禦によつて, 社会・経 済的な変動を乘り越えようとしてきた。これらの立地条件を担いながら，各工場には， 時の流れの中に, その分布の態様の変化が現われた。

工場は，古い集落に集中していたが，集落のフロンテイアを形成しながら，次第に市 の北東部や, 南東部へも拡散した。これらの小工場は, 社会の変容にしたがつて, 種々 の製品を生み出しながら，古い製品を捨てることなく，衣料品の生産を続けている。

\section{5.日本の木造船工業横浜国立大学 伊 東進}

\section{一特に下田・三崎・小名浜について一}

海囲まれた我国では，古くから木造船による海上輸送や漁業が発達したため，これ に従つて木造船も発達したのであり，銅船時代の今日尚千余の木造船所を数える。筆者 は，ここに斯業発達の歴史と現在の地域的分布及びその要困について若干の考察を進め, 特に下田・三崎・小名浜についてその現状を報告する。木造船工業の全国分布は, 太平 洋岸が主で, それも西日本, 特に瀬戸内海に多い。約半数が個人業で殆ど小規模な中小 企業である。斯業の立地として, 古くは沿岸各地で行われたが, 造船所への発達は, (1)港との関係であり，下田は漁業根拠地や迴船港が，(2)木材供給をえて発達し，それと 対応して帆船漁船専門に別れ，以後も斯業の先進地となつて関連業も発達した。同様な 要因をもつ三崎は，木材不足から小型船建造の個人船大工にとどまつたのである。又小 名浜汢築港により，直接的には企業合同を端緒としたが，木材供給もあつた。木材の多 
量需要から原料指向性が港を基盤烤克られ，それはコストに影響する。次に，(3)貨金 そついては, 地方性が考光られ，これは叉，斯業の持続関係する。その他，(4)戦時の

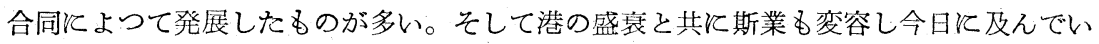
るが，先にあげた立地要因が伝統的要因として技術・設備等にも影響しているのである。 現状は，漁業の消長に影響されて，小名浜以外は不振である。乙かし，小名浜も季節的 繁閑の為, 年労㗢日数は少ない。かかる不振と斯業性格のが見習工の不足を来している 事は共通的である。不振に対し鋼船業化への対策を講じている所もあるが，他は資金問 題がある。かかる不振は, 漁船業のみでなく, 全国的に斯業にみられ, これは需要減や 資金の回転不良等に上るのであつて，今後，コストの引下げや内外の需要開拓及び鋼船 業への考慮が必要と思われる。

\section{6. 都市および周辺の人口増加の過程とその交通機関におよぼす}

\section{影響 一東京・中央線沿線の場合一横浜市大 吉 沢 孝 輔}

年々橧加する東京の人口と，拡大されていく都市地域が，かつては，ぞのような姿で

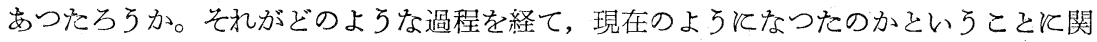
心をるつた。

都市地域の拡がりそついて考察するためと，私はとの場合，人口統計を主として用い

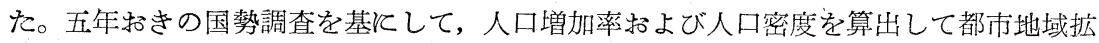
大の数值とした。

また，本諭の対象として選しだ地域は，中央線が終始同一行政区内をはしるといらこ と他ならない。

対象とする地域と, 都区部と郡部（主として北多摩郡）と飞太別して，それぞれの特 色を年代別々のべた。年代は，前述のよ 5 K，大正九年第一回国勢調査から第二回目 （大正一四年）末でを第一期として，以下各五年毎飞期を定めて第七期昭和二五年から 三○年に至つている。

都市地域の拡大は，鉄道によつて促進・助長された（その他の理由るあるが，乙の場 合は考兄交いととにして）特に郡部々执いては, 電車運転開始以前の姿から, 電車開通 後の変化, 戦争前, 戦争中, 戦争後とその時期時期飞よつて興味深い。

都市化がすすんで，周辺地区の人口増加の速度が，鉄道を主とする交通機関の発達， 輸送力増加つ速さよりも急激であつたために，通勤その他の求心的交通が，鉄道などの 輸送力を超觉つつある。

即ち, 現在の姿孫, 種々不合理な点が多く, その不合理な点を指摘して, そう応急 恒久の対策を考光るととなぞである。

\section{7. 長崎県的山大島における人口増減の地理学的研究}

日本大学 松 田明

明治19年以降の的山大島に挌ける人口増減の状態を男女別に分けて比較すると, 明治 年間注男女共飞順調な増加を示しているが，大正年間に入つてふらはそれぞれ人口増 減の年代や増减率を異てしている。男子は大正 4 年には 2309 人であつたのが大正 9 年に 
は3055人というょ3に激増し, それ以降は逆に減少して昭和10年には 2495 人となつてい る。女子は明治 44 年には 2371 人であつたのが，大正 4 年には 2671 人とい5よ5に増加し， それ以降は停滞的で䀡和10年には2596人をなつている。かかる男女相異なる現象を生ず るに至つた原因は, 的山大島の位置が魚種豊富な対馬暖流の環流する所にあり, 南岸に は的山港と神浦港の好錨地を有するが故に, 明治35年頃から他町村出漁者の根拋地とし て利用され，これらの者が大正 9 年の第一回国勢調查により現住者として統計上に現れ た汹めで, 大正 9 年の水産業と交通業の世帯人員（男子 $=1180$ 人，女子 $=514$ 人）は男 子の流入により不均衡となり, 皇を船頭や船夫を相手とする飲食業・芸者業が湾頭に発 生したために女子が流入し，商業の世帯人員（男子 $=117$ 人，女子 $=293$ 人）も不均衡之 なつた。このために人口は増加し, 湾頭には小さな港湾都市を形成して活気があつた。

かかる人文現象が起つたのも櫓船時代飞招ける位置的・地形的有利条件によるるので あるが, 大正初年動力漁船の出現を見, それが普及するに伴い, 根抛地としての機能 は裹微し，的山大島を根挞地とする他町村出漁者の流出をみるに至つた。これが大正 9 年から昭和10年末でに減少した原因であり，それは大正 9 年から昭和 5 年の間に減少し た人口 250 人の5ち，自身出生者の 48 人に対し，他町村出生者が 202 人であることによ つても証明される。他町村出生者の減少は全て男子によるもので, 女子はるずか増加 している。

つまり的山大島の大正期前半の人口増加は, 售船時代飞他町村出漁者の根拠地之京り, 男子が流入したためで, それ、伴つて飲食業, 芸者業が発生し, 女子も流入した。大正 9 年以降の減少は動力漁船の出現によるものである。

\section{8. 農村人口移動の分布}

一甲府盆地酉半部の調查報告一 山梨大学山本仁

1. 目的 山梨県は全国的に見て, 人口の停滯乃至減少する県の一つである。その 原因は，自然增の少なることにるよるが，それ以上に人口の流出現象の結果である。本

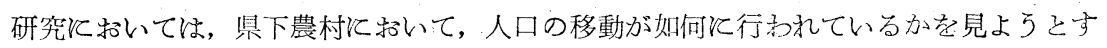
るものである。

2. 方法人口移動を移動地域, 移動形態, 及びその経済的な面から明ふにする。 調查地域としては県下中巨摩郡 (甲府盆地西半部) を選び，その概観を把握し，更に沖 積原の水田地帯, 扇状地上の畑作地带, 山間農村からそれぞれ一ケ村ずつ三村（南湖, 西野, 芦安) をとり, 村役場に控ける最近数年間の資料の調查と, 聞き之りによる補い の調查とによつた。

3. 成果 各村共通の一般的傾向と, 各村特有の特殊的傾向とが見られる。一般的 傾向としては,

(1) 過去数年間常に檕出の方が多いが，1954年頃より転出の減少が晃られる。ここに 都市ふら農村への逆流の兆がうかがえる。

(口) 移動地は京浜地带が多く, 職業的移動が大部分を占める。県内では, 甲府及ざ同 郡中巨揫に多く, 職業的移動之共飞非職業的移動子多い。

(0) 階層別（耕地反別）には 5 反以下及び 1 町以上に移動が多い。前者は職業的移動 